\title{
STUDY PENERAPAN PENGELOLAAN SAMPAH DI TPA KUPANG KECAMATAN JABON KABUPATEN SIDOARJO
}

\author{
Putri Nevy Dewi Tara, Bambang Sunarko, Ferry Kriswandana
}

\begin{abstract}
Garbage is resulted from human activities and their existence is unwanted. High population growth can cause an increase in garbage volume. This situation calls for right and proper garbage management. Such garbage management can be done in the landfill.

The research was carried out in Kupang Landfill at Kecamatan Jabon Kabupaten Sidoarjo. This was a descriptive study, using cross sectional approach. This study illustrated the garbage management implementation in Kupang Landfill in Kecamatan Jabon Kabupaten Sidoarjo in 2014. The data were analysed descriptively based on the tabulated data using fulfillment standard as $>50 \%$.

The results indicated a score of $65 \%$ on garbage management implementation in the Landfill that is in accordance with the Minister of Public Works Regulation Number 3 Year 2013 regarding The Implementation of Garbage Infrastructure in Household Garbage Handling and Garbage Similar to Household Garbage. The garbage management method adopted in Kupang landfill is a controlled landfill. Garbage comes from residential areas, markets and manufacturing companies or industries. The daily generation rate of garbage is in the average of $376 \mathrm{~m}^{3} /$ day. The type of the produced garbage is household garbage and similar to those . In terms of the composition it consists of organic and inorganic garbage. The equipment and tools being used in garbage management are dump truck, arm roll, pick up, bulldozer, broom, small water pump, big diesel engine, and methane gas suck blower.

It is suggested to perform some sorting between garbage from manufacturing companies or industries with public garbage. Garbage grouping is based on garbage composition which can be expressed in \% of weight or $\%$ of volume of each garbage composition, conduct garbage sorting and grouping since garbage leaves its sources, provide sorting facilities, a place for every type of garbage, and provide sorted garbage collection facility.
\end{abstract}

Keywords : Final Processing, Garbage Management

\section{PENDAHULUAN}

Sampah tidak dapat dipisahkan dari kehidupan manusia, sebab pada dasarnya sampah merupakan produk yang sebetulnya tidak diharapkan adanya. Namun kenyataan ini tidak dapat dihindarkan. Timbulnya sampah yang berakumulasi menyebabkan manusia berupaya untuk mengatasinya, sebab telah diyakini adanya beberapa pengaruh negatif yang ditimbulkan oleh karenanya.

Jumlah penduduk Indonesia yang besar dengan tingkat pertumbuhan yang tinggi mengakibatkan bertambahnya volume sampah. Di samping itu, pola konsumsi masyarakat memberikan kontribusi dalam menimbulkan jenis sampah yang semakin beragam, antara lain, sampah kemasan yang berbahaya dan sulit diurai oleh proses alam.

Kabupaten Sidoarjo, adalah sebuah kabupaten di Provinsi Jawa Timur, Indonesia. Ibukotanya adalah sidoarjo. Kabupaten ini berbatasan dengan Kota Surabaya dan Kabupaten Gresik di Utara, Selat Madura di timur, Kabupaten Pasuruan di selatan, serta Kabupaten Mojokerto di barat. Kabupaten Sidoarjo memiliki luas sebesar 591,59 $\mathrm{Km}^{2}$.
Jumlah penduduk Kabupaten Sidoarjo dengan tingkat pertumbuhan yang relatif tinggi membawa akibat bertambahnya volume sampah. Pertambahan jumlah volume sampah adalah berbanding lurus dengan pertambahan jumlah penduduk. Volume sampah anorganik semakin bertambah seiring dengan pola konsumtif kehidupan masyarakat yang terus berkembang.

TPA (Tempat Pemrosesan Akhir) Pemerintah Kabupaten Sidoarjo terletak di Desa Jabon, Kecamatan Kupang. Luas Iahan TPA tersebut sebesar 5,4 Ha. Kapasitas TPA Kupang Kecamatan Jabon sudah melebihi / over load sehingga ada kemungkinan DKP (Dinas Kebersihan dan Pertamanan) Kabupaten Sidoarjo akan melakukan pelebaran lahan TPA.

Rumusan masalah pada penelitian ini adalah Bagaimana pengelolaan sampah TPA Kupang Kecamatan Jabon Kabupaten Sidoarjo ? Tujuan pada penelitian ini adalah menggambarkan penerapan pengelolaan sampah di TPA Kupang Kecamatan Jabon Kabupaten Sidoarjo tahun 2014.

\section{METODE PENELITIAN}

Jenis penelitian ini adalah penelitian deskriptif. Objek penelitian adalah proses pengelolaan 
pembuangan sampah akhir di TPA, evaluasi, dan analisis. Teknik pengumpulan data menggunakan observasi, wawancara, dokumentasi. Teknik analis data adalah editing dan tabulating dengan penyajian data dalam bentu tabel, dan dalam narasi deskriptif.

\section{HASILPENELITIANDAN PEMBAHASAN Sumber Sampah}

Sumber sampah yang ada di TPA Kupang berasal dari perumahan, pasar, dan umum seperti pabrik atau industri di Kabupaten Sidoarjo. Jenis sampah yang dibuang di TPA Kupang yaitu tumbuhan, sisa makanan, sayur-sayuran, buah-buahan, kardus, kertas, botol minuman, kaleng, kaca, dan plastik. komersial seperti pasar, kawasan industri, fasilitas umum seperti jalan, trotoar. Sampah tersebut termasuk sebagai sumber sampah rumah tangga dan sumber sampah sejeris rumah tangga.
Sumber sampah tersebut berupa jenis sampah yang mudah terurai, sampah yang dapat digunakan kembali, dan sampah yang dapat di daur ulang.

\section{Komposisi Sampah}

Komposisi sampah yang berada di TPA Kupang Kabupaten Sidoarjo terdiri dari sampah organik dan anorganik. Sampah organik terdiri dari sisa makanan, sayur-sayuran dan buah-buahan serta bagian-bagian tumbuhan seperti daun dan batang yang dibuang. Sedangkan untuk sampah anorganik terdiri dari kertas, plastik, botol minuman, kaleng, dan pecahan kaca.Komposisi sampah tidak dapat dinyatakan sebagai \% berat atau \% volume dari masing-masing komposisi sampah. Hal ini dikarenakan dimulai dari sumber sampah sampai dengan di TPA tidak dilakukan pemilahan sampah sesuai dengan jenis sampah.

\section{Volume Sampah}

Berikut adalah hasil perhitungan rata-rata volume sampah:

Tabel 1 : Rata-rata Volume Sampah

\begin{tabular}{|c|c|c|c|c|c|}
\hline No & $\begin{array}{l}\text { Sumber } \\
\text { Sampah }\end{array}$ & Alat Angkut & Jumlah & $\begin{array}{c}\text { Rata-rata } \\
\text { Volume Bak } \\
\text { Sampah } \\
\left(\mathrm{m}^{3}\right)\end{array}$ & $\begin{array}{l}\text { Rata-rata Volume Sampah per } \\
\text { hari }\left(\mathrm{m}^{3} / \text { hari }\right)\end{array}$ \\
\hline \multirow[t]{3}{*}{1} & \multirow{3}{*}{ Perumahan } & Arm Roll & 1 & \pm 6 & \pm 6 \\
\hline & & Dump Truk & 22 & \pm 10 & \pm 220 \\
\hline & & Pick up & 6 & \pm 4 & \pm 24 \\
\hline \multirow[t]{2}{*}{2} & \multirow{2}{*}{ Pasar } & Arm Roll & 1 & \pm 6 & \pm 6 \\
\hline & & Dump Truk & 12 & \pm 10 & \pm 120 \\
\hline \multicolumn{5}{|c|}{ Jumlah } & $\pm 376 \mathrm{~m}^{3} /$ hari \\
\hline
\end{tabular}

Volume sampah yang berasal dari perumahan dan pasar yang dapat diangkut dengan kendaraan yang ada dan dibuang ke TPA Kupang adalah kurang lebih sebanyak $376 \mathrm{~m}^{3} /$ hari. Setiap harinya rata-rata volume sampah tersebut adalah sama, kecuali hari minggu. Pada hari minggu hanya ada

\section{Sistem Pengelolaan Pembuangan Sampah di TPA Kupang}

Sistem pengelolaan pembuangan sampah di TPA Kupang saat ini menggunakan metode controlled landfill dan beroprasi sejak tahun 2006 dengan luas lahan $\pm 5 \mathrm{Ha}$. Metode tersebut merupakan sarana pembuangan sampah yang bersifat antara, sebelum mampu melaksanakan operasi sanitary landfill dan merupakan metode peningkatan dari metode open dumping.Dimana proses pengelolaan sampah tersebut adalah sampah yang diangkut oleh truk sampah setiap hari dan dibuang ke TPA kemudian sampah tersebut diratakan dan dipadatkan menggunakan alat berat yaitu bego dan buldoser. Setelah tumpukan beberapa truk yang melakukan aktivitas pengangkutan sampah dari sumber sampah. Untuk sampah yang bersumber dari umum seperti pabrik, dalam melakukan pembuangan di TPA Kupang dalam waktu satu tahun hanya tiga sampai empat kali pengangkutan.

sampah tersebut padat, tumpukan sampah tersebut dijadikan atau dibentuk menjadi sebuah sel-sel. Tinggi tumpukan sampah tersebuat kurang lebih $7 \mathrm{~m}$. Kemudian sampah yang sudah dipadatkan tersebut dilapisi dengan tanah kurang lebih setinggi $5 \mathrm{~cm}$. Untuk melapisi sampah tersebut dengan tanah tidak bisa rata, dikarenakan pengaturan tersebut menggunakan bego. Tumpukan sampah dilapisi dengan tanah bertujuan unyuk mengurangi bau, mengurangi perkembangbiakan lalat, dan mengurangi keluarnya gas metan. Di TPA Kupang terdapat beberapa fasilitas yang ada, diantaranya yaitu saluran pengumpul air lindi (leachate) yang dihasilkan oleh sampah tersebut, fasilitas pengendalian gas metan, alat berat. 
Peralatan yang Digunakan dalam Pengelolaan Sampah di TPA

Berikut ini adalah peralatan yang digunakan dalam pengelolaan sampah di TPA:

Tabel 2 Peralatan Dan Perlengkapan Pengelolaan Sampah

\begin{tabular}{|c|l|c|}
\hline No & \multicolumn{1}{|c|}{ Jenis } & Jumlah \\
\hline 1 & Dump truk & 53 buah \\
\hline 2 & Arm roll & 14 buah \\
\hline 3 & Pick up & 6 buah \\
\hline 4 & Buldoser & 1 buah \\
\hline 5 & Bego & 2 buah \\
\hline 6 & Sapu lidi & 2 buah \\
\hline 7 & Pompa air kecil & 1 buah \\
\hline 8 & Diesel besar & 1 buah \\
\hline 9 & Blower penghisap gas metan & 1 buah \\
\hline
\end{tabular}

Dump truk, arm roll, dan pick up berfungsi sebagai alat angkut sampah yang berasal dari sumber sampah. Didalam pengelolaan sampah di TPA Kupang buldoser digunakan untuk meratakan dan memadatkan sampah. Untuk alat berat bego terdapat 2 buah yaitu bego type PC 100 yang digunakan untuk memindahkan sampah dari tempat satu ke tempat lainnya dan bego kecil yang digunakan hanya untuk tindakan diluar TPA yaitu untuk pengurangan volume sampah. 2 buah sapu lidi digunakan untuk membersihkan sampah yang berserakan jatuh di jalan masuk menuju
TPA. Pompa air kecil digunakan untuk menyalurkan air, dimana aiir tersebut berfungsi untuk menyirami jalan masuk ke TPA agar tidak gersang dan berdebu. Diesel besar digunakan untuk pengurasan air lindi (leachate) yang dihasilkan oleh sampah pada waktu musim hujan. Sedangkan blower digunakan untuk pengambilan gas metan atau penyadapan gas metan dari jarak jauh.

Penilaian Pada Penerapan Pengelolaan Sampah di TPA

Berikut ini adalah hasil Penerapan pengelolaan sampah di TPA Kupang Kabupaten Sidoarjo

Tabel 3: Rekapitulasi Hasil Observasi Penerapan Pengelolaan Sampah Di TPA Kupang Kabupaten Sidoarjo

\begin{tabular}{|c|l|c|c|c|c|}
\hline No & \multicolumn{1}{|c|}{ Tahapan } & $\boldsymbol{\Sigma}$ Ya & $\boldsymbol{\Sigma}$ Tidak & $\%$ Nilai & Keterangan (MS/TMS) \\
\hline 1 & Pemilahan Sampah & 0 & 3 & 0 & TMS \\
\hline 2 & Pengumpulan Sampah & 1 & 3 & 25 & TMS \\
\hline 3 & Pengangkutan Sampah & 5 & 1 & 83,3 & MS \\
\hline 4 & Pengolahan & 4 & 0 & 100 & MS \\
\hline 5 & Pemrosesan Akhir & 3 & 0 & 100 & MS \\
\hline
\end{tabular}

Keterangan : Memenuhi syarat jika mendapatkan skore $50-100 \%$.

Tidak memenuhi syarat jika mendapatkan skore $<50 \%$.

Dari hasil observasi penilaian penerapan pengelolaan sampah di TPA Kupang Kabupaten Sidoarjo mendapatkan skore $65 \%$, sehingga penerapan pengelolaan sampah di TPA Kupang menurut Peraturan Menteri Pekerjaan Umum Republik Indonesia Nomor 3 Tahun 2013 tentang Penyelenggaraan Prasarana dan Sarana Persampahan Dalam Penanganan Sampah Rumah Tangga dan Sampah Sejenis Sampah Rumah Tangga telah memenuhi persyaratan pengelolaan sampah

\section{KESIMPULAN}

Sumber sampah di TPA berasal dari perumahan, pasar dan umum seperti pabrik atau industri di Kabupaten Sidoarjo. Komposisi sampah yang ada pada TPA Kupang Kabupaten Sidoarjo terdiri dari sampah organik dan anorganik. Sampah organik meliputi sisa makanan, sayur-sayuran, buahbuahan, serta bagian-bagian tumbuhan seperti daun dan batang. Sedangkan sampah anorganik meliputi kertas, plastik, botol minuman, kaleng, dan pecahan kaca. Volume sampah yang dihasilkan oleh warga kurang lebih $376 \mathrm{~m}^{3} /$ hari. Jenis sampah yang ada pada TPA Kupang Kabupaten Siodarjo adalah sampah rumah tangga dan sampah sejenis rumah tangga. TPA Kupang Kabupaten Sidoarjo dalam sistem pengelolaan pembuangan sampah saat ini menggunakan metode controlled landfill. Peralatan dan Perlengkapan yang digunakan dalam pengelolaan sampah di TPA Kupang Kabupaten Sidoarjo adalah dump truk, arm roll, pick up, buldoser, bego, sapu lidi, pompa air kecil, diesel besar, dan blower penghisap gas metan. Tahapan pengelolaan sampah yang dilakukan di TPA Kupang Kabupaten 
Sidoarjo adalah pengumpulan sampah, pengangkutan sampah, pengolahan sampah, dan pemrosesan akhir sampah. Di TPA Kupang Kabupaten Sidoarjo tidak melakukan tahapan pemilahan sampah. Pada penilaian penerapan pengelolaan sampah di TPA Kupang Kabupaten Sidoarjo mendapatkan skore $65 \%$, sehingga penerapan pengelolaan sampah di TPA Kupang menurut Peraturan Menteri Pekerjaan Umum Republik Indonesia Nomor 3 Tahun 2013 tentang Penyelenggaraan Prasarana dan Sarana Persampahan Dalam Penanganan Sampah Rumah Tangga dan Sampah Sejenis Sampah Rumah Tangga telah memenuhi persyaratan pengelolaan sampah.

\section{SARAN}

Dilakukan pengelompokkan sampah berdasarkan komposisi sampah yang dapat dinyatakan sebagai

\section{DAFTAR PUSTAKA}

Balai Teknik Air Minum dan Sanitasi Wilayah 2, 2010. Materi Pelatihan Berbasis Kompetensi Bidang Persampahan. Wiyung - Surabaya.

Berita Sidoarjo, 2013. Pembangunan TPA Kebonagung Tahun 2013 Ini Tertunda. http://Berita/Sidoarjo/BB/Pembangunan ITPA/Kebonagung/2013/Ini20Tertunda. htm. 23 Desember 2013

Damanhuri, Enri dan Tri Padmi, 2010. Diktat Pengelolaan Sampah. Bandung. Edisi Semester 1- 2010/2012 Program Studi Teknik Lingkungan Fakultas Teknik Sipil dan Lingkungan

Koran Madura, 2013. Produksi Sampah 3.600 Kubik per Hari. http://Produksi/Sampah/3.600/Kubik/p er/Hari/Koran/Madura.htm. 23 Desember 2013

Mulia. Ricki M., 2005. Kesehatan Lingkungan. Yogyakarta, Graha Ilmu. Cetakan Pertama

Nazir, Moh., 2003. Metode Penelitian. Jakarta, Ghalia Indonesia. Edisi kelima

Notoadmodjo, Soekidjo., 1997. I/mu Kesehatan Masyarakat, Rineka Cipta. Cetakan Pertama
$\%$ berat atau $\%$ volume dari masing-masing komposisi sampah. Sebaiknya untuk pengukuran volume sampah ditimbang dan dicatat terlebih dahulu sebelum truk sampah memindahkan sampah di area pembuangan sampah.Dilakukan pemilahan dan pengelompokkan sampah mulai dari sumber sampah paling sedikit 5 jenis sampah yaitu sampah yang mengandung bahan berbahaya dan beracun, sampah yang mudah terurai, sampah yang dapat digunakan kembali, sampah yang dapat didaur ulang, dan sampah lainnya (residu).Untuk lebih meningkatkan sistem pengelolaan sampah dengan menggunakan metode sanitary landfill.Tetap mempertahankan peralatan dan perlengkapan yang ada dan digunakan dalam pengelolaan sampah.Menerapkan pengelolaan sampah sesuai dengan peraturan perundang-undangan tentang pengelolaan sampah.

Notoadmodjo, Soekidjo., 2012. Metodelogi Penelitian Kesehatan. Jakarta, Rineka Cipta

Undang-undang Nomor 18 Tahun 2008 Tentang Pengelolaan Sampah.

Peraturan. Daerah Kabupaten Sidoarjo No. 6 Tahun 2012 Tentang Pengelolaan Sampah Dan Retribusi Pelayanan Persampahan Kebersihan.

Peraturan Menteri Pekerjaan Umum Repulik Indonesia Nomor 03/PRT / M / 2013 Tentang Penyelenggaraan Prasarana dan Sarana Persampahan Dalam Penanganan Sampah Rumah Tangga Dan Sampah Sejenis Sampah Rumah Tangga.

Sarudji MsC, Didik., 1985. Pengelolaan Sampah. Surabaya, Akademi Penilik Kesehatan

Sejati, Kuncoro., 2009. Pengolahan Sampah Terpadu. Yogyakarta, Kanisius. Edisi Pertama

Sugiyono, 2011. Metode Penelitian Kuantitatif Kualitatif Dan R\&D. Bandung, Alfabeta

Sumantri, Arif., 2010. Kesehatan Lingkungan \& Perspektif Islam. Jakarta, Prenada Media. Edisi Pertama 